\title{
Patterns, causes and consequences of land use/cover dynamics in the Gumara watershed of lake Tana basin, Northwestern Ethiopia
}

\author{
Mesfin Anteneh Wubie ${ }^{1 *}$, Mohammed Assen $^{2}$ and Melanie D. Nicolau ${ }^{3}$
}

\begin{abstract}
Background: This study was aimed at examining land use/cover changes over 48 years and its causative factors in the Gumara watershed of Lake Tana basin, Northwestern Ethiopia. Two sets of aerial photograph (1957 and 1985) and a multispectral Spot5 image (2005) were used as inputs to produce three GIS-based land cover maps of the study area. Socio-economic surveys, focus group discussion and field observation were also used to determine the cause and effects of these land use/cover dynamics.

Results: The results showed that cultivated and settlement land expanded by $21.99 \%$, whereas forest land, shrub land, grass land and wetland declined by $85.30,91.39,76.15$ and $72.54 \%$ over the analysis period respectively. Population pressure, demand for fuel wood and construction material, agricultural expansion and policy and tenure insecurity were the major driving forces behind the land use/cover change. Environmental and local livelihoods implications such as lake water and its aquatic resources and soil degradation, biodiversity loss and forest cover decline are resulted from the changes.

Conclusion: The cumulative effect of these implications caused poverty and environmental degradation. Hence, there should be strategies of managing open access resources through participation of local people in the management. There should also be appropriate land use planning by identifying the proper land for specific purpose so that the marginal lands will not be put into agricultural use.
\end{abstract}

Keywords: Gumara watershed, Land use/cover change, Remote sensing, Socio-economic factors

\section{Background}

Land use/cover (LULC) is the most prominent form of the global environmental change phenomenon occurring at spatial and temporal scales. Land cover is the physical and biological cover of the surface of the land, whereas land use is the indicator of complex human activities that alter land surface processes (Foley et al. 2005). The conversion of natural land to anthropogenic landscapes represents the form of human impact on the environment (McGranham et al. 2005). Roughly $40 \%$

\footnotetext{
*Correspondence: mesfin74@yahoo.com

${ }^{1}$ Department of Geography and environmental studies, Bahir Dar

University, Bahir Dar, Ethiopia

Full list of author information is available at the end of the article
}

of the earth's land surface is under agriculture and $85 \%$ has some level of anthropogenic influences (Sanderson et al. 2002). Therefore, large scale land cover change is largely a rural phenomenon but many of its drivers can be traced to the consumption demands of the swelling urban population (Carr 2004). Land degradation, desertification, biodiversity loss, habitat destruction and species transfer are consequences of converting natural land covers (Meyer and Turner 1995). The relationship between land cover and land use change and its causative factors is complex and dynamic. It is manipulated by both natural and socio-economic factors. Some studies suggest that demographic dynamics contribute more than any other processes to land cover changes (Mather and

\section{贷 Springer}


Needle 2000). Others suggest the superiority of economic factors to be the major contributing factor (Lambin and Geist 2001). Some socio-economic factors of land cover change include poverty, tenure insecurity, and availability of market and credit facilities (Campbell et al. 2005). These factors have become apparent between and within individual regions and countries. Thus the diversity of causative factors of land use change must be considered within the regional variations (Lambin and Geist 2006).

As in the other parts of the world, major land cover changes have also been occurred in Ethiopia. For instance, a significant increase in cultivated land at the expense of forest land was found to have occurred at local and regional levels. These include in northwest (Gete and Hurni 2001), northeastern (Kebrom and Hedlund 2000), western (Bezyayehu and Gerret 2008), central (Aklilu 2006) and eastern (Mohammed 2011) Ethiopia. On the other hand, deforestation trend was reduced through appropriate interventions by promoting planting of local tree species in parts of the Blue Nile Basin, Ethiopia (Woldeamlak 2002). Bedru (2006) reported that from 1973 to 2000 agriculture alone was the driving force for 83.4 and $70.1 \%$ of the natural vegetation loss in Abijata Shala National Park (ASNLP) and Zway-Awasa Basin respectively.
Information on local level land use dynamics is essential for designing sound environmental policies and management. It provides a base line data required for proper understanding of how land was used in the past and the type of changes to be detected in the future. This research was therefore aimed at analyzing the link between land cover dynamics and its contributory factors in the Gumara watershed (north western Ethiopia). Identifying land use changes behind and developing appropriate measures to minimize the ecological effects have great deal of importance for land use planning. Therefore, this study analyses historical patterns of land use/cover and evaluates its causes and consequences that occurred between 1957 and 2005 in the study watershed.

\section{Methods}

\section{The study area}

Gumara watershed is found in north western Ethiopia, located between latitudes $11^{0} 34^{\prime}-12^{0} \mathrm{~N}$ and longitudes $37^{0} 33^{\prime}-38^{0} 11^{\prime} \mathrm{E}$ (Fig. 1). The elevation ranges from 1784 to $3408 \mathrm{~m}$ above mean sea level (amsl). It has $1470.20 \mathrm{~km}^{2}$ and forms a part of Lake Tana basin forming the source of Blue Nile, North western Ethiopia. A mountainous and hilly dissected terrain with steep slopes characterises the upper stream whereas an undulating

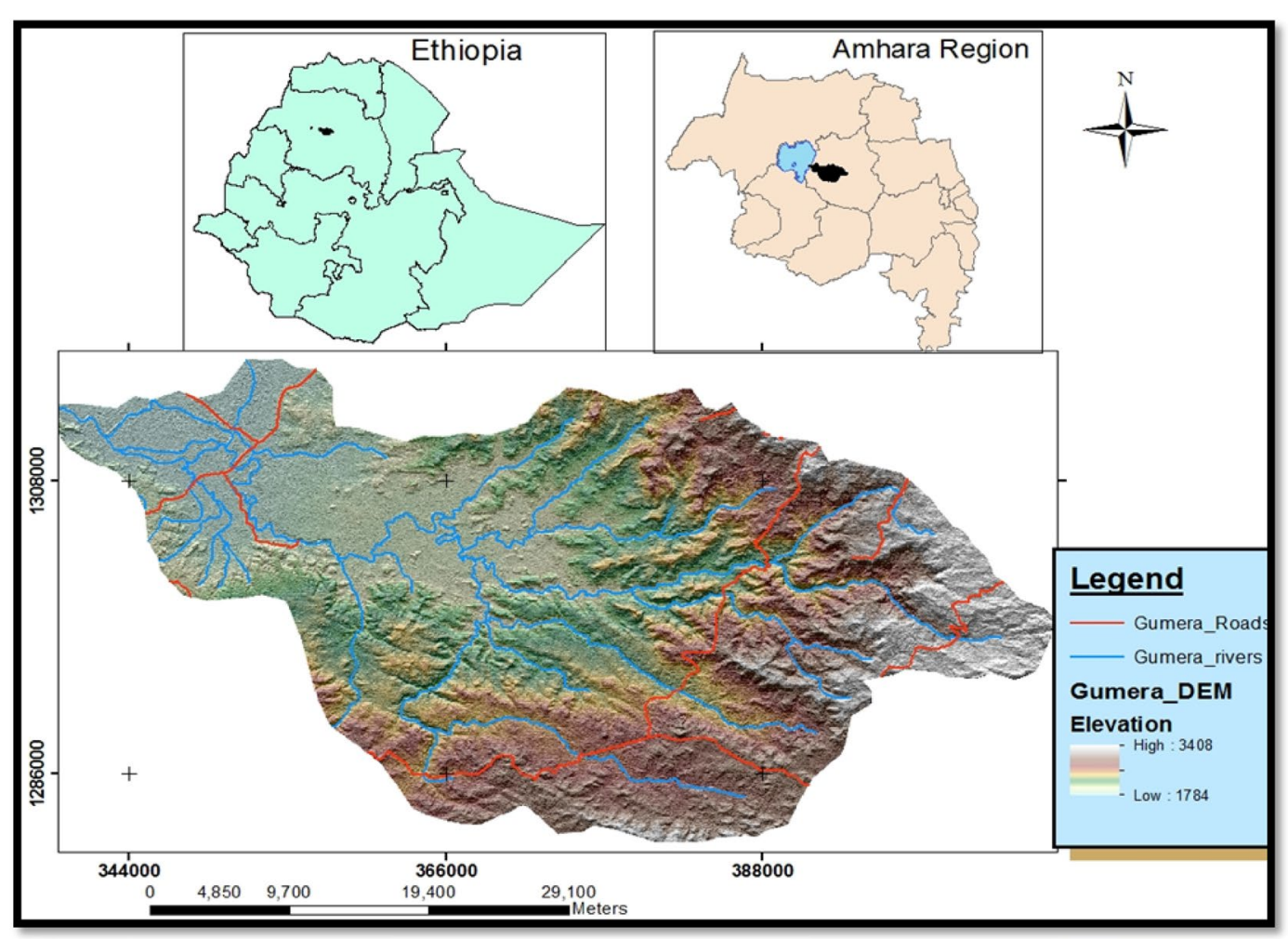

Fig. 1 Location map of the study area 
topography and gentle slopes form the downstream parts of the study watershed. The area is drained by numerous smaller streams including Guamra (the largest stream in the watershed) that flow to Lake Tana.

The soils covering much of the watershed can be classified into clay loam, sandy loam and clayey to silt clayey. The clay loam soils are imperfectly to poorly drained soils occupying the Fogera-Dera flood plains adjoining Lake Tana where the Gumara river ends. The well drained sandy loam soils are very shallow and eroded covering steeper slopes. The clay to silt clay soils occur on nearly level to gently undulating land occupying the mid stream and downstream parts of the watershed.

The climatic type is generally humid (EMS 2013). The mean annual temperature is $20.5^{\circ} \mathrm{C}$ and the average total annual rainfall is $1300 \mathrm{~mm}$. More than $75 \%$ of the total rainfall occurs in the months of June-September (kiremt season) (Fig. 2). Corresponding to topographic variation, different natural vegetation types were observed in the area. As a result Juniperous podocarpus (locally called Tid) and Juniperous procera (locally referred to as Zigba) $\mathrm{a}=$ were found at elevation of 3000 masl. Whereas Dodonaera anguistifola (locally known as Kitkita) and Euclea Schimpera (known locally as Dedeho) were found between 1900 and 2200 masl. Syzgim guineense (locally known as Doqima) and Ficus sp. (locally named as warka) found in gentler slopes and along stream banks.

The total population of the watershed was 198,879 (1984) and 485,816 (2007) and 487,576 (2013) (CSA 2007; South Gondar Zone Office of Agriculture 2013). This gave a corresponding population density of 135.2, 330.4 and $331.7 \mathrm{p} / \mathrm{km}^{2}$ Subsistence mixed (crop and animal) agriculture is the major means of livelihood in the area with an average farm size of about one hectare (ha). The common growing crops are maize (Zea mays L.), teff (Ergarostis teff Zucc), rice (Oryza galberrima) and beans (Phaseolus vulgaris L.). Other less important crops include chickpea (Cicer arietinum), potato (Solanum tuberosum), onion (Allium cepa), cabbage (Brassia aleracea) and Chilie pepper (Capsicum spp.). Various types of crops such as, garlic (Alliium sativum), Ethiopian mustard (Brassica carrinata), oats (Avena sativa) and carrot (Dancus carota sativus) are also cultivated as cash crops. Domestic animals such as cattle, goat, sheep, donkey, chicken and bees are kept on traditional basis.

\section{Data acquisition and analysis}

Two sets of 1:50,000 panchromatic aerial photographs taken in 1957 and 1985 and a multispectral (three band) spot image dated 2005 were used as major data sources. The watershed boundary was determined on the 1:50,000 topographic map. The available aerial photographs were scanned with a 600 dots per inch scanner. This was then geo-referenced according to the Universal Transverse Mercator (UTM) system using 1:50,000 topographic maps as base map. Geo-referencing the Spot image in the same projection using the same topographic sheets and delimiting and cutting out the study watershed by tracing it from 1:50,000 topographic maps were followed. The demarcated study area was digitized in Arc GIS 10, and then super imposing the view on spatial data bases created from the photographs and the satellite image.

The identification and classification of land use/cover types on the aerial photographs was undertaken by visual interpretation with mirror stereoscope. Thus, six land cover classes were recognized and identified (Table 1).

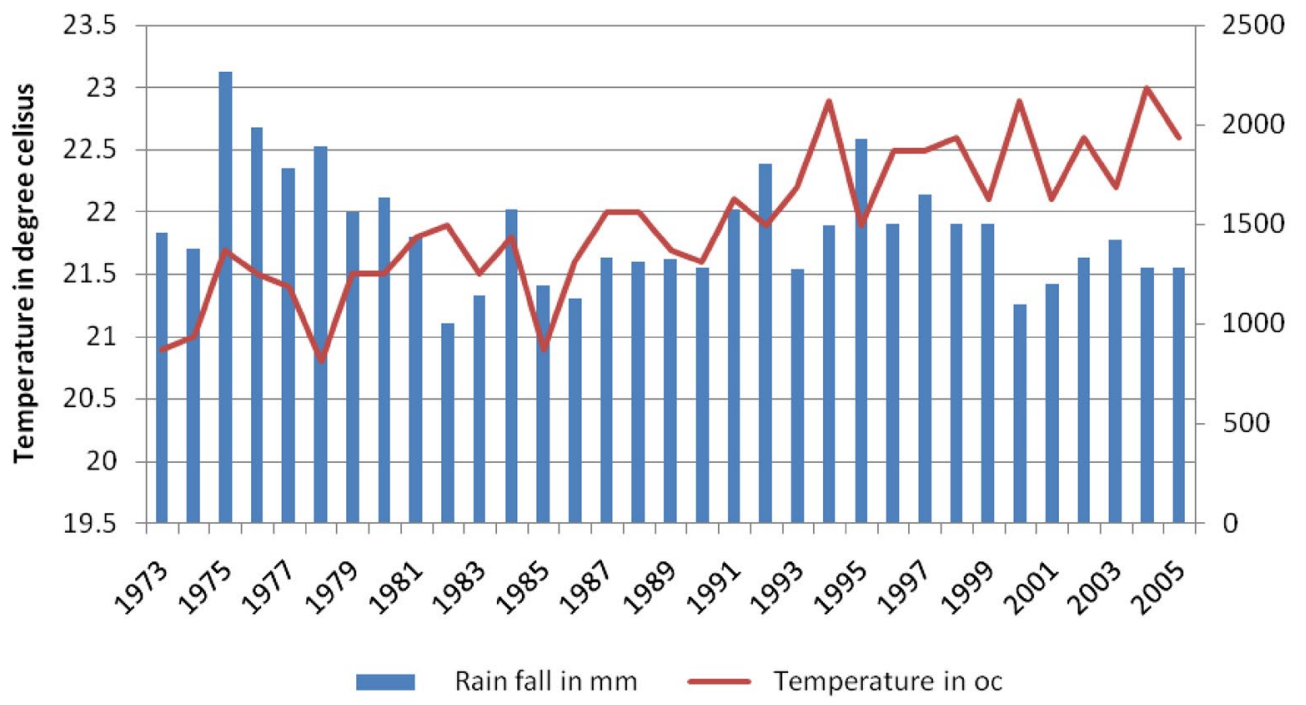

Fig. 2 Mean annual rainfall and temperature of the Gumara catchment (Ethiopian Metrological Service 2013) 
The land cover classes from the spot image were also generated by visual interpretation and on-screen digitizing using Arc Info 10 on the basis of reflectance characteristics (false color composite) of the different land cover types. This was supplemented by a number of field visits that made it possible to establish the main land cover types. For the purpose of comparison, many land use/ cover types produced from the multi- spectral spot image were synchronized to fit into the six classes defined from the black and white aerial photographs. In doing so, reducing the number of classes, proper care was taken to minimize errors due to generalization.

ERDAS Imagine 10 and its peripheries were used to analyze the spatial data bases created. Finally, three land use/cover maps were produced corresponding to the three reference years, and temporal changes in land use/cover were determined. In order to substantiate the information obtained from the aerial photo and satellite image, we conducted socio-economic surveys of households between July and September 2013. The purpose of the survey was to acquire data that would assist in explaining the socio-economic and demographic condition of rural households and communities as well as the cause and consequences of land use change. Therefore, we selected a total of 120 households' i.e. 40 households from three elevation classes [lower (1784-1999 masl), middle 2000-2499 masl and upper (2500-3408 masl)]. Moreover, focus group discussion was conducted with a group of farmers that constitutes two elderly people with the age of 65 and 71 , four young women and men with the age between 23 and 25. An interview was also held with the key informants selected from experts and elderly people of the village that have adequate knowledge about the general condition of the study area.

\section{Patterns of LULC Change}

The land use/cover trend analysis made for the two consecutive periods 1957-1985 and 1985-2005 has indicated that the watershed was subject to considerable land use changes (Figs. 3, 4, 5). The conversion of natural forests and wetland to cultivated and settlement land is major change observed in the study period.

\section{Wetland}

Wetland of the Gumara watershed was located in the low lying area around the shores of lake Tana. It was one of the most disturbed land use type by human-induced LULC dynamic (Table 3). Its conducive topography for agriculture together with the introduction of rice in the late 1970s contributed to the high level of influence of human activities. As a result, the land use type showed continuous decline throughout the study period. During the initial study period, the wetland covered $0.66 \%$ (970 ha) of the total area of the watershed (Table 2). However, its size is reduced by $60.57 \%$ (587 ha) between 1957 and 1985 (Table 3). The change detection matrix showed that about $84.63 \%$ ( 821 ha), $4.74 \%$ (46 ha), $3.60 \%$ (35 ha) and $0.25 \%$ ( $2.5 \mathrm{ha}$ ) was shifted to cultivated and settlement land, shrub land, forest land and grassland respectively from 1957 to 1985 (Table 4). The declining trend continued in the following analysis period (1985-2005) by $30.6 \%$ ( $166 \mathrm{ha}$ ). This was due to the conversion of $95.28 \%$ (364 ha) and $0.13 \%$ ( 0.5 ha) of the wetland to the cultivated and settlement land and forest land respectively (Table 5; Figs. 3, 4, 5).

\section{Shrub land}

The area under shrub land cover showed a declining trend. It declined by $58.11 \%$ (7189 ha) from $8.40 \%$ of total cover (12367 ha) in 1957 to $3.57 \%$ (5178 ha) in 1985 (Table 2). As the change result matrix revealed, about $81.17 \%$, (10038.31 ha), $3.29 \%$ (408 ha) and $3.08 \%$ (381 ha) of the shrub land was changed to cultivated and settlement land, forest land and grass land respectively from 1957 to 1985 . However shrub land gained $6.11 \%$ (1291 ha), $4.81 \%$ (191 ha) and 1.94 \% (2150 ha) land from forest land, grass land and cultivated and settlement land respectively in the same study period (Table 4). Similarly the land use continued its declining trend between 1985 and 2005. Accordingly, the land use type shrunk from $3.52 \%$ (5178 ha) in 1985 to $0.73 \%$ (1064 ha) in 2005. The

Table 1 Description of the land cover classes identified in the Gumara watershed, Ethiopia

\begin{tabular}{|c|c|}
\hline Land use/cover type & Description \\
\hline Wetland & $\begin{array}{l}\text { Areas that are water logging and swampy during the rainy season and dry during the dry season, perennial marshy } \\
\text { areas and riparian vegetation }\end{array}$ \\
\hline Shrub land & Areas covered with shrubs, bushes and small trees, with little useful wood, mixed with some grasses \\
\hline Cultivated and settlement land & $\begin{array}{l}\text { Areas used for crop cultivation both annuals and perennials and the scattered rural settlement that are closely associ- } \\
\text { ated with the cultivated fields }\end{array}$ \\
\hline Forest land & Areas covered by trees both natural and planted \\
\hline Grassland & $\begin{array}{l}\text { Grassy areas used for communal grazing, as well as a bare land that has very little or no grass cover (exposed rocks) } \\
\text { but with the same tone on the air photos }\end{array}$ \\
\hline
\end{tabular}


largest proportion of shrub land, $80.23 \%$ (4154 ha), was converted to cultivated and settlement land, followed by forest land and grassland that constitutes $7.89 \%$ (408 ha) and $7.12 \%$ (369 ha) respectively (Table 5 ). Whereas the largest share of $1.94 \%$ (2150.58 ha) the shrub land gained from other land use during this time was from the cultivated and settlement land (Table 4). This is probably due to the desertion of some portion of cultivated land which was formerly changed from the forest land.

\section{Cultivated and settlement land}

During the entire period the area under cultivated and settlement land increased persistently from $75 \%$ (110, $678 \mathrm{ha})$ in 1957 to $92 \%(134,944 \mathrm{ha})$ in 1985 and $96 \%$ (141,887 ha) in 2005 (Table 2). The trends showed a consistent expansion of cultivated and settlement land over the four decades being analyzed (1957-2005). Accordingly, there was an increase of $17.89 \%$ (24,266 ha) between 1957 and 1985 and $4.89 \%$ (6943 ha) between 1985 and 2005 (Table 3). As it was outlined by the participants of the focus group discussion, the relatively smaller change observed in this land use type during the 2005 study period was because of the fact that farmers were forced to abandon and leave the cultivated land for grazing purpose due to the declining of its soil fertility status. As the detection analysis results revealed this observed consistent expansion was attributed to the conversion of the wetland, shrub land, grass land and forest cover into cultivated and settlement land at different stages. For instance, between 1957 and 1985 the cultivated and settlement LULC category exhibited a net gain of $84 \%$ of wetland, $81 \%$ of shrub land, $78.6 \%$ of grassland and $78 \%$ of the forest cover, while cultivated and settlement land maintained about $95.9 \%$ of the original size to remain under the same land use category (Table 4) similarly in the period between 1985 and 2005, the land under cultivation and settlement achieved a considerable net gain of $5.90 \%$ (7974 ha) of which shrub land covered $3.07 \%$ (4154 ha), forest land $1.66 \%$ (2245 ha) and grassland $1.16 \%$ (1575 ha) (Table 5). In the contrary, the conversion of cultivated and settlement land to the other LULC classes was relatively insignificant. Generally, throughout the study period (1957-2005) cultivated and settlement land cover increased by $21.99 \%$ (31209 ha) with annual average rate expansion of $0.45 \%$ (Table 3; Figs. 3, 4, 5)

\section{Forest land}

Forest land was the second largest LULC class type next to cultivated and settlement land cover, with the share of $13.06 \%(19,227$ ha) of the total area of the study watershed in 1957 (Table 2). Although this land use type constituted significant share at the beginning of the study period, there was a significant decline over the study period; from $13.06 \%(19,227 \mathrm{ha})$ in 1957 to

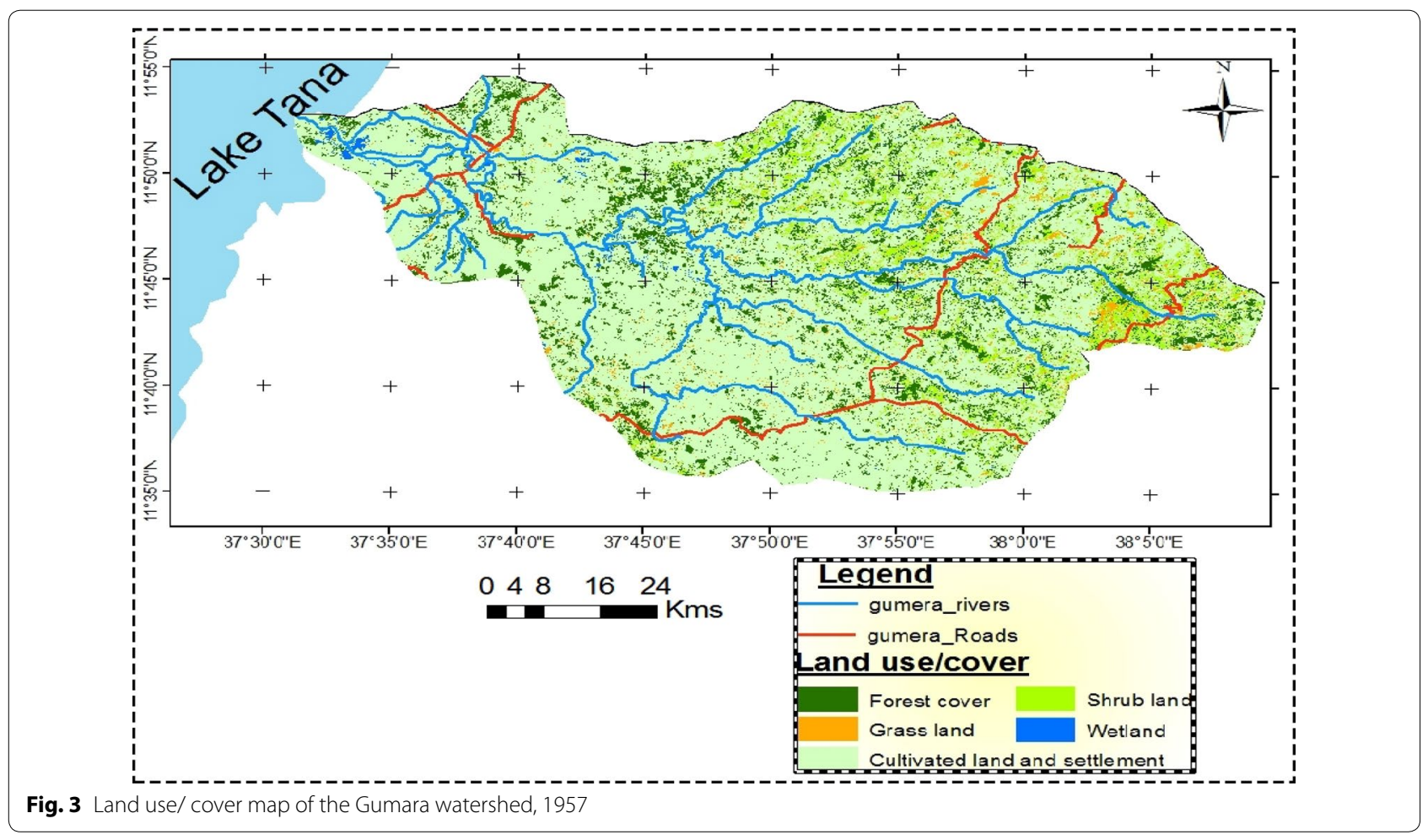



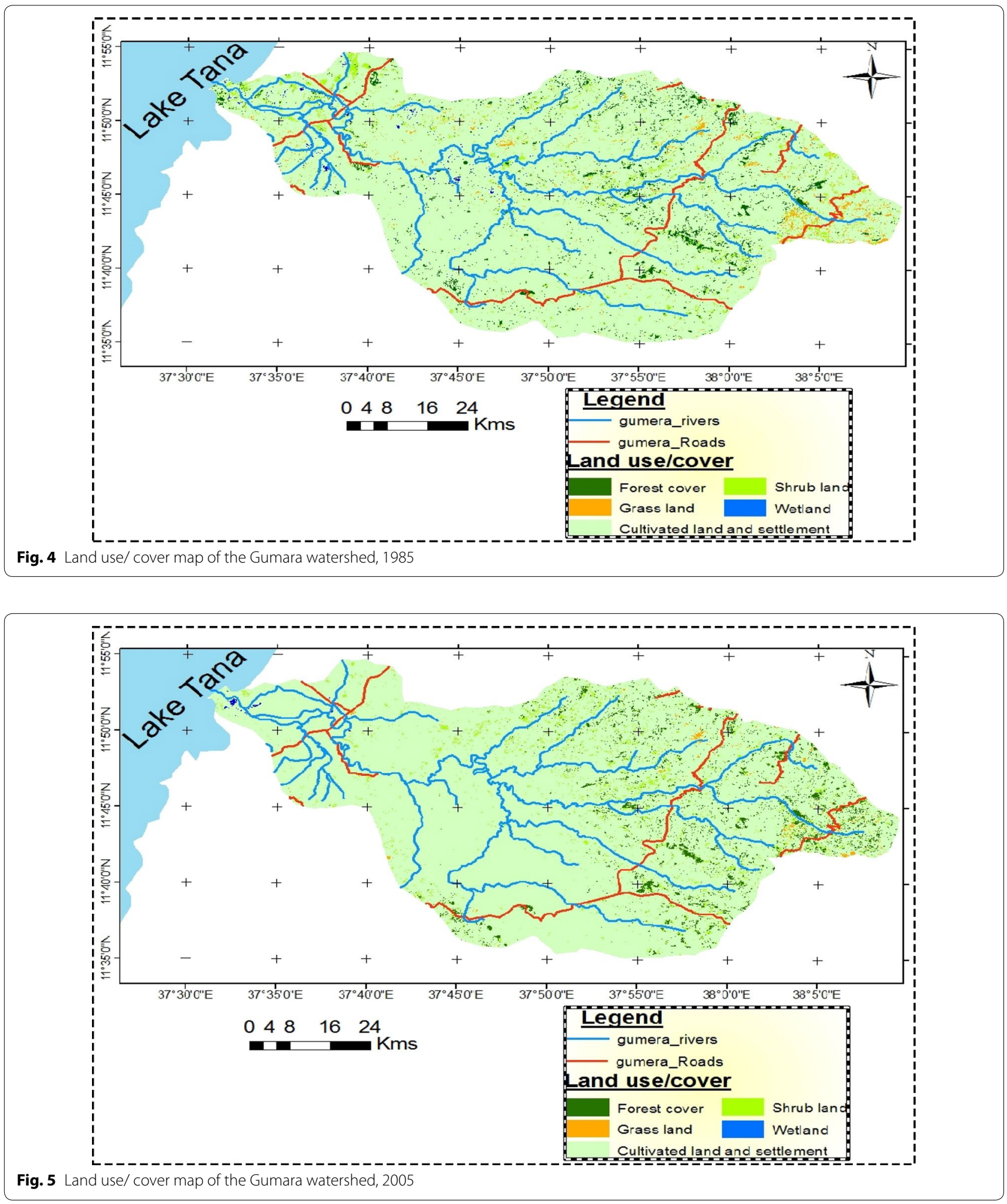

$3.15 \%$ (4633 ha) in 1985 and to $1.93 \%$ (2826 ha) in 2005 (Table 2). The change detection matrix result showed the largest portion of this land use type, $72.55 \%$ (14,459 ha) and $6.11 \%$ (1219 ha) was shifted to cultivated and settlement land and shrub land between 1957 and 1985 respectively (Table 4). Similarly in the period between 
Table 2 Areas of LULC in different study periods in the Gumara watershed

\begin{tabular}{|c|c|c|c|c|c|c|}
\hline \multirow[t]{2}{*}{ Land use /cover classes } & 1957 & $\%$ & 1985 & $\%$ & 2005 & $\%$ \\
\hline & \multicolumn{2}{|l|}{ Area (ha) } & \multicolumn{2}{|l|}{ Area (ha) } & \multicolumn{2}{|l|}{ Area (ha) } \\
\hline Wetland & 969.95 & 0.66 & 382.77 & 0.26 & 266.56 & 0.19 \\
\hline Shrub land & 12,367 & 8.40 & 5178.78 & 3.52 & 1064.25 & 0.73 \\
\hline Cultivated and settlement & $110,678.54$ & 75.19 & 134,944 & 91.72 & $141,887.32$ & 96.53 \\
\hline Forrest land & $19,227.40$ & 13.06 & 4633.02 & 3.15 & 2826.36 & 1.93 \\
\hline Grassland & 3963.96 & 2.69 & 1992.87 & 1.36 & 945.99 & 0.65 \\
\hline Total & $147,206.66$ & 100 & $147,206.44$ & 100 & $147,206.47$ & 100 \\
\hline
\end{tabular}

Table 3 Rate of LULC dynamics (1957-2005) in the Gumara watershed

\begin{tabular}{|c|c|c|c|c|c|c|c|c|c|}
\hline \multirow[t]{3}{*}{ Landuse/cover classes } & \multicolumn{3}{|c|}{ 1957-1985 } & \multicolumn{3}{|c|}{ 1985-2005 } & \multicolumn{3}{|c|}{ 1957-2005 } \\
\hline & \multicolumn{2}{|c|}{ Total change } & \multirow{2}{*}{$\begin{array}{l}\text { Annual change } \\
\%\end{array}$} & \multicolumn{2}{|c|}{ Total change } & \multirow{2}{*}{$\begin{array}{l}\text { Annual change } \\
\%\end{array}$} & \multicolumn{2}{|c|}{ Total change } & \multirow{2}{*}{$\begin{array}{l}\text { Annual change } \\
\%\end{array}$} \\
\hline & $\mathrm{Ha}$ & $\%$ & & $\mathrm{Ha}$ & $\%$ & & $\mathrm{Ha}$ & $\%$ & \\
\hline Wetland & -587 & -60.57 & -2.16 & -116 & -30.36 & -1.5 & -703 & -72.54 & -1.54 \\
\hline Shrub land & -7189 & -58.13 & -2.07 & -4144 & -79.54 & -3.97 & $-11,303$ & +91.39 & -1.90 \\
\hline Cultivated and settlement land & +2426 & +17.98 & +0.64 & +7974 & +4.89 & +0.24 & $+31,209$ & +21.99 & +0.45 \\
\hline Forest land & $-14,594$ & -75.90 & -2.7 & -1807 & -39.00 & -1.95 & $-16,401$ & -85.30 & -1.77 \\
\hline Grass land & -1971 & -49.73 & -1.77 & -1047 & -52.56 & -2.68 & -3018 & -76.15 & -1.58 \\
\hline
\end{tabular}

Table 4 Land use/cover matrix change from 1957 to 1985

\begin{tabular}{|c|c|c|c|c|c|c|c|c|}
\hline \multirow{3}{*}{$\begin{array}{l}\text { Change from/to } \\
1957\end{array}$} & \multicolumn{6}{|c|}{ Land use/cover classes for 1985} & \multicolumn{2}{|c|}{ Change in 1985} \\
\hline & \multirow[b]{2}{*}{ WL } & \multirow[b]{2}{*}{ SH } & \multirow[b]{2}{*}{ CUL/SET } & \multirow[b]{2}{*}{ FOR } & \multirow[b]{2}{*}{ GR } & \multirow[b]{2}{*}{ Total } & \multirow{2}{*}{$\begin{array}{l}\text { Class } \\
\mathrm{Ha}\end{array}$} & \multirow{2}{*}{$\begin{array}{l}\text { Area } \\
\%\end{array}$} \\
\hline & & & & & & & & \\
\hline WL & 64.23 & 1.26 & 276.82 & 32.54 & 4.89 & 379.74 & -590.32 & -60.85 \\
\hline $\mathrm{SH}$ & 46.12 & 1537.16 & 2150.58 & 1219.80 & 191.02 & 5144.68 & -7221.49 & -58.39 \\
\hline CUL/SET & 821.41 & $10,038.31$ & $105,843.63$ & $14,459.97$ & 3118.71 & $134,286.92$ & $23,620.62$ & 21.34 \\
\hline FOR & 35.64 & 408.38 & 1508.09 & 4129.53 & 34.79 & 4605.43 & -7760.75 & -42.14 \\
\hline GR & 2.59 & 381.06 & 887.18 & 84.22 & 613.76 & 1968.81 & -1994.36 & -50.32 \\
\hline Total & 970.06 & $12,366.17$ & $110,666.30$ & $19,927.06$ & 3963.17 & $147,206.58$ & & \\
\hline
\end{tabular}

WL wetland SH shrub land CUL/SET cultivated and settlement land FOR forestland GR grassland

Table 5 Land use/cover change matrix from 1985 to 2005

\begin{tabular}{|c|c|c|c|c|c|c|c|c|}
\hline \multirow{3}{*}{$\begin{array}{l}\text { Change from/to } \\
1985\end{array}$} & \multicolumn{6}{|c|}{ Land use/cover classes for 2005 (ha) } & \multicolumn{2}{|c|}{ Change in 2005} \\
\hline & \multirow[b]{2}{*}{ WL } & \multirow[b]{2}{*}{ SH } & \multirow[b]{2}{*}{ CUL/SET } & \multirow[b]{2}{*}{ FOR } & \multirow[b]{2}{*}{ GR } & \multirow[b]{2}{*}{ Total } & \multirow{2}{*}{$\begin{array}{l}\text { Class } \\
\text { ha }\end{array}$} & \multirow{2}{*}{$\begin{array}{l}\text { Area } \\
\%\end{array}$} \\
\hline & & & & & & & & \\
\hline$W L$ & 16.11 & 38.88 & 198.54 & 13.32 & 0 & 266.85 & -115.92 & -30.28 \\
\hline $\mathrm{SH}$ & 0 & 455.46 & 478.8 & 82.53 & 47.52 & 1066.41 & -4112.37 & -79.40 \\
\hline CUL/SET & 364.5 & 4154.94 & $132,502.86$ & 2245.58 & 1575.03 & $141,963.57$ & +7974.91 & +5.20 \\
\hline $\mathrm{FO}$ & 0.5 & 408.38 & 1142.64 & 1281.15 & 35.28 & 2832.12 & -1800.9 & -38.87 \\
\hline GR & 0 & 369.81 & 484.11 & 84.22 & 298.8 & 938.07 & -1054.8 & -52.92 \\
\hline Total & 382.77 & 5178.78 & $134,943.66$ & 4633.02 & 1992.87 & $147,206.58$ & & \\
\hline
\end{tabular}

WL wetland SH shrub land CUL/SET cultivated and settlement land FOR forestland GR grassland 
1985 to $2005,48.54 \%$ (2245 ha) $1.81 \%$ (84 ha) and $1.76 \%$ (82 ha) of the forest land was converted to cultivated and settlement land, grass land and shrub land respectively (Table 5). However, only $7.89 \%$ (408 ha) of shrub land, $1.75 \%$ (35 ha) grass land and $0.84 \%$ (1142 ha) of cultivated and settlement land was changed to forest land (Table 5). The change analysis result showed that the largest portion of forest land was converted to cultivated land and bush land. This implies that a continuous and exhaustive thinning of forestry resources for diverse uses, particularly for construction, firewood and agricultural tools which eventually led to the degradation of forest to bush land and then to cultivated land. This result is also consolidate the response of the local communities participated in the focus group discussion (Figs. 6, 7).

\section{Grass land}

Grass lands in the watershed were found in pockets of land around homesteads and farm sides reserved for grazing, and extensive communal grazing fields with free grazing away from home mainly in valley bottom

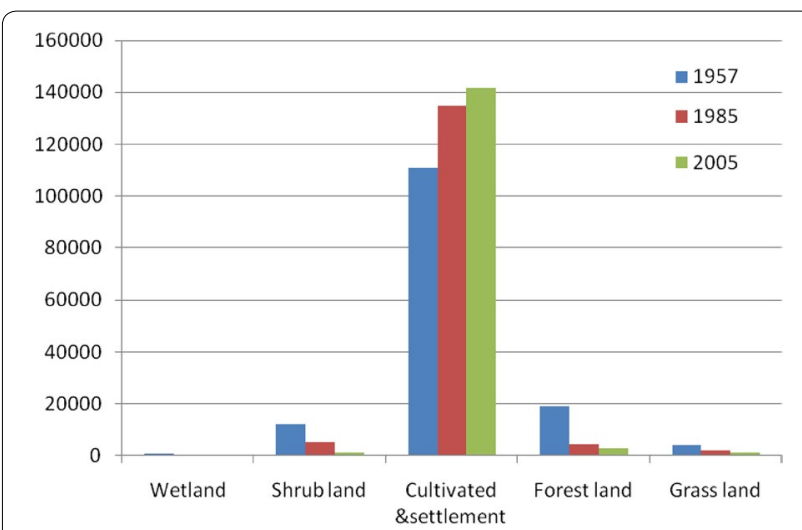

Fig. 6 Trends of the LULC dynamics in the Gumara watershed

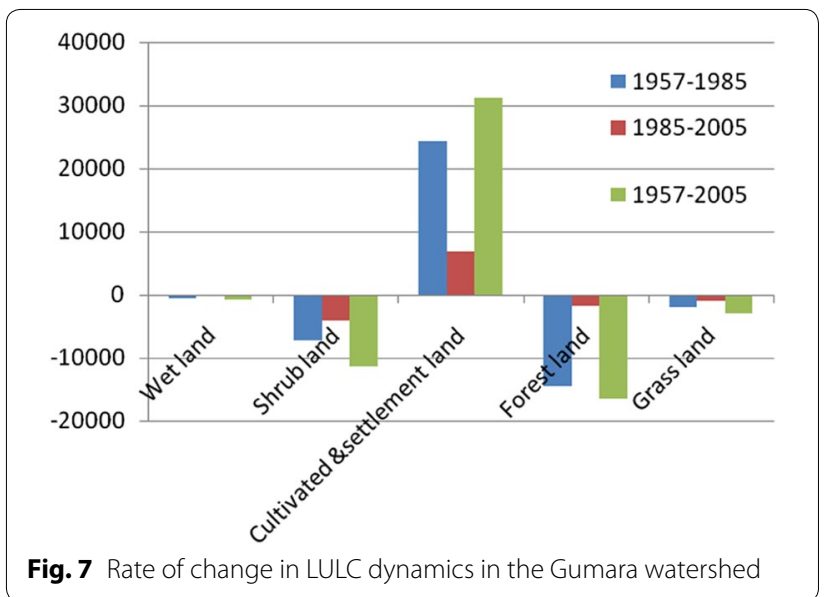

and plains. The land use type covered $2.69 \%$ (3963 ha) of the total area of the study watershed in 1957. However, trends shown by the LULC dynamic analysis indicated that there was a significant decline in grass land cover over the study period: from $2.69 \%$ (3963 ha) in 1957 to 1.36 \% (1992 ha) in 1985 and to 0.65 \% (945 ha) in 2005 (Table 2). The change detection matrix result showed that about $78.67 \%$ (3118 ha) of the grass land was shifted to cultivated and settlement land between 1957 and 1985 . A similar pattern of change was observed in the subsequent analysis period. From the total area converted, $41.81 \%$ (1657 ha) changed to other LULC types that included $39.74 \%$ (1575 ha), $1.18 \%$ (47 ha) and $0.88 \%$ (35 ha) to cultivated and settlement land, shrub land and forest land respectively between 1985 and 2005 . However only $0.80 \%$ (887 ha) of cultivated and settlement land was converted to grassland (Table 4). Generally, the overall grassland transferred to other LULC categories during the two consecutive study periods was $76.15 \%$ (3018 ha), with annual decline of $1.58 \%$ (62.87 ha) (Tables 3 , 4 and 5; Figs. 3, 4 and 5). This continuous shift of grass land to cultivated and settlement land may be attributed to the rapidly growing demand for cultivated and settlement land which is directly related to the continuous demand for more cultivation and settlement land caused by an increment of population in the watershed.

\section{Causes of land use/cover dynamics}

\section{Population pressure}

Change in population size, distribution and associated demographic characteristics are often considered as the most important factors affecting land use distribution and change (Turner and Meyer 1994). Accordingly, $79.4 \%$ of the respondents reported that population growth and increasing land scarcity, which is the effect of the former, as the factor of the first order of importance of land use change in the watershed. Fast population growth and the consequent high pressure on resources are expected to have an adverse effect on the existing natural resources of the area. Such rapid population growth in the area has already exerted pressure on the existing land resources through increasing the demand for food, wood for fuel and construction material purpose and other necessities. Substantial increase in demand for food has resulted in an expansion of croplands by encroaching on uncultivated areas including forest, shrub and wetlands. This has resulted in deforestation and soil degradation. Similarly, increased demands for fuel wood in the absence of alternative sources of energy have led to the destruction of forests. They have also led to the increased use of crop residues and animal dung for fuel rather than using these as a source of organic fertilizer to replenish the fertility levels of the soil. 


\section{Expansion of Agriculture and introduction of new type of cropping}

As clearly indicated in the LULC dynamic analysis, the area under cultivated and settlement land showed significant increase in the Gumara watershed over the 48 year period (1957-2005). A significant number of respondents (67.3\%) also indicated that the expansion of crop production was the main driving force of the LULC dynamics in the study area (Table 6). This is probably due to two reasons. First, in order to meet the food demand following the increasing population in the area, the then government introduced rice (a high yielding crop) since 1978. Due to this, a greater portion of the wetland was changed into farm land. According to the participants of the focus group discussion, the wetland of Gumara watershed was used as the grazing land before the introduction of rice production to the area. However, presently due to its high yield nature and its high price in the market compared to other food crops, people of the study area prefer to grow rice instead of other crops. Second, there was also establishment of agricultural producer cooperatives starting from the early 1980 s by the government in order to motivate them to devote their time in farming activities. This change in agricultural policy together with the introduction of rice farming caused the expansion of agricultural land at the expense of other land use types in the area.

\section{Demand for fuel wood and construction material}

The majority of sample households (80\%) of the study area use wood for cooking, heating and as a source of light. This activity has contributed a lot for the destruction of forest in the watershed. Participants of the focus group discussion expressed that the forest which is found in the Gumara watershed is not only used for the satisfaction of their energy need but also as a means additional income activities. The timber obtained from the catchment was also used for sale in the nearby urban areas as constructional as well as fuel wood materials. As a result, growth of the nearby towns (e.g. Gumara, Hamusit, Woreta and Debre Tabor) puts pressure on the available resources of the watershed (Fig. 8). The increasing number of population which is directly related to shortage

Table 6 Perceptions of local population on the causes of LULC in the Gumara watershed

\begin{tabular}{lll}
\hline Causes of land use/cover change & Frequency & Percent \\
\hline Population pressure & 95 & 79.4 \\
Expansion of agriculture & 80 & 67.3 \\
Demand for fuel and construction material & 74 & 63.3 \\
Poverty & 64 & 54.2 \\
Policy and institutional change & 52 & 43.3 \\
\hline
\end{tabular}

of cultivated land has also forced farmers to depend on selling firewood and charcoal for supplementary income, and this has also contributed to the destruction of the woody biomass and shrub land.

\section{Poverty}

Poverty is linked to land cover changes in that the poor over use the natural resources to escape from poverty. Amare and Rao (2012) have shown that in Ethiopian highlands, rural poor households have caused land degradation. According to the empirical evidences obtained from the households in the study area, their average income is below the poverty line. In most cases, the amount of income generated from land by individual households ranged between US $\$ 100$ and US \$1005/ annum with a mean income of US $\$ 575$, which means less than US $\$ 2$ a day. In the same way, about $50 \%$ of the interviewed households confirmed that poverty is one of the causes for LULC dynamic and land degradation particularly deforestation (Table 6). They pointed out that most households in the watershed obtained additional income for living particularly during the period of agricultural drought from other sources such as selling fire wood, aquatic grass of the wetland and others that are obtained from the exploitation of natural resources. Over exploitation of natural resources without using proper management techniques cause the depletion of natural resources such as soil and forest. Therefore, poverty is one of the major reasons that caused damage on natural resources in the watershed.

\section{Policy and institutional changes}

Most households and farmers involved in the focus group discussion explained that much of the expansion of croplands and the lost of forest cover took place during the 1970s and 1980s. This explanation is well related to the evidences in LULC dynamics obtained from the digital imagery analysis. These can be inferred from the political events that took place in the country; the land reform of 1975 confiscated all rural lands and distributed these to the rural tenants. At that time, arable lands were abundant in most places of the watershed and the population pressure was low as a result of which poorly drained soils and hilly areas were not turned to cultivation. However, as a result of the frequent redistribution and the later land reform act of the 1997 particularly enacted in the Amhara Region (Zikre Hig of the Council of the Amhara National Regional State 1997), more fragile land areas were converted to cultivation. The land redistribution of the 1997 was mainly from communal holds (grazing lands) and land from the holdings of the so-called "bureaucrats" who were dispossessed because they were at different administrative positions in the ex-military 


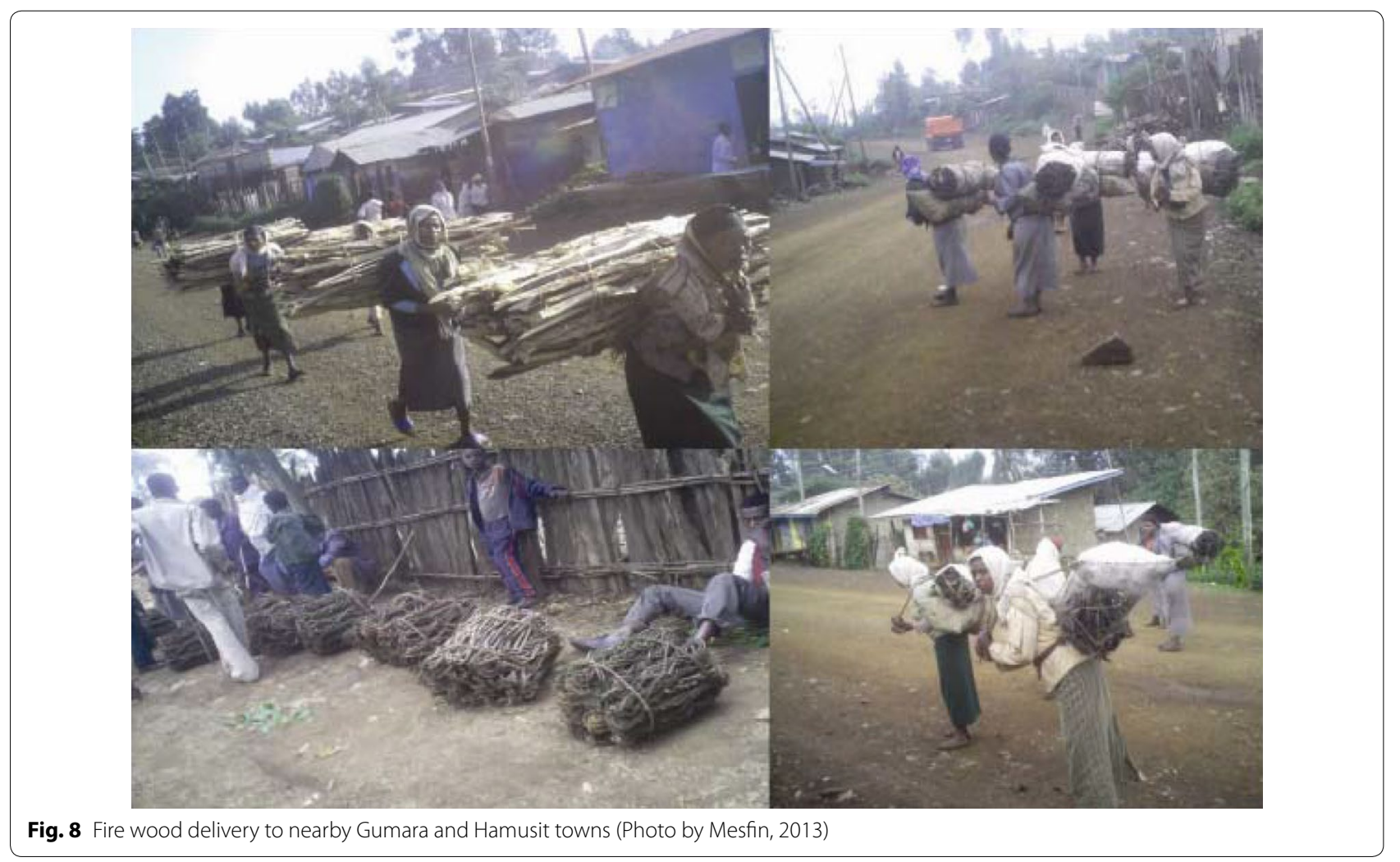

rule, which reigned from 1974 to 1991 . As a result, the land which was used for communal grazing land was converted to the crop land, and the bureaucrats whose land was dispossessed became dependent on selling forest products.

\section{Consequences of LULC change in the Gumara watershed Biodiversity loss}

According to the key informants, due to absence of clear forest tenure system the forest trees of the catchment were indiscriminately destroyed. As a result, indigenous trees such as Juniperous procera, Millettia ferugunea and Ximenia ameriicana which were once occupying the area are on the way to disappear. Today, these indigenous trees are found only in protected areas, such as church yard monasteries and inaccessible steeper mountainous areas. In many parts of the watershed the indigenous trees are replaced by exotic trees like eucalyptus. As it was explained by the key informants, the decline of forest cover caused a decline in the number of wild animals. In some cases animals such as tiger, lion and antelope which were commonly found in the watershed before 40 years ago disappeared. Thus the conversion of forest land to other type of land use caused numerous negative impacts on the ecosystem as well as the livelihood of the society in the study area.

\section{Soil erosion}

The persistent deforestation happened in the watershed for decades due to different human activities especially for crop production together with the rugged landscape has exposed the study watershed to soil erosion. According to the information obtained from the DAs' (Development Agents) of the study watershed used as a key informant, $30 \%$ of the upper slope and $25 \%$ of the middle slopes are seriously affected by soil erosion. The explanation given was that much of the uplands and the escarpments were characterized by different humaninduced practices such as the clearing of natural vegetation for different uses, cultivation of steep slopes, inappropriate farming system and absence of soil conservation and soil fertility management methods. As a result, they lose much of their soil through water runoff. Field observation in such areas recorded sheet erosion as well as numerous gullies that originated from the escarpment running down ward to the lower positions of the watershed (Fig. 9).

In the lower positions of gentle slopes, the gullies tend to narrow and become shallower because of the sedimentation process of the materials transported from upper slopes. However, the accumulation of sediments and its water logging nature especially during rainy season as well as soil depletion due to repeated cultivation were 
common agricultural problems in the low-lying areas of the study watershed. According to farmers, this decline in soil fertility, soil erosion caused by deforestation and intensive cultivation of steeper slopes has resulted in a decline in agricultural production and productivity. These forced farmers to put more land under cultivation in order to maximize their agricultural produce. As a result, wetlands which were used as grazing land became converted to agricultural land. This has also its own impact on the loss of habitats of aquatic animals. For instance, following the cultivation of rice in the wetlands, native grass is replaced by the water hyacinth, which is poisonous and not palatable by animals. Similarly, the size of fish and other aquatic animals living in the nearby lake (Lake Tana) declined due to the percolation of agricultural chemicals to the lake.

\section{Scarcity of firewood}

Participants of the focus group discussion explained that the destruction of the forest has negatively affected their benefit obtained from the watershed. One of these effects is scarcity of fire wood and construction materials. This effect is particularly serious in the low-income households whose livelihood is directly related to the collection of fire wood and production of charcoal for both their domestic consumption and source of income through selling to the residents of the nearby towns. As a result, in particular rural women have been forced to walk long distance for fire wood. This reduces the time available for farming and household activities. Moreover, the scarcity increased the price of available firewood to the point where there is no longer affordable for some households including in the nearby towns. This situation caused many households to turn to animal dung and crop residues as alternative source of fuel. However, the removal of biomass from fields in turn reduced the organic matter being added to the soil, which would otherwise have improved the soil structure and soil fertility. This may critically affect agriculture and agricultural productivity as one of the major source of food insecurity in developing countries such as Ethiopia. Similarly, the shortage of construction materials forced households to depend largely on less durable and easily affected Eucalyptus trees for house construction and agricultural tools.

\section{Impacts on livelihood}

As explained by participants of the focus group discussion, the continuous dwindling of forest cover caused scarcity of wood for fuel and construction material. As a result, income obtained from the selling of wood and wood products declined. In the same way, following the introduction of rice farming in the watershed the largest portion of wetlands has changed into agricultural land; due to this the common papyrus grass used by women for the making of household utensils both for their own use as well as a source of income disappeared from the area. As a result, people of the watershed who were previously engaged in selling of fire wood and charcoal, basketry work as well as crop production slowly changing their livelihood to daily labourer and in some cases to offfarm activities such as poultry, fattening of animals and selling of local drinks.

\section{Conclusion}

This study analyzed land use/cover dynamics from 1957 to 2005. The result showed that cultivated and settlement land expanded by $21.99 \%$ whereas forest land, shrub land, grass land and wetland declined by $85.30,91.39$,

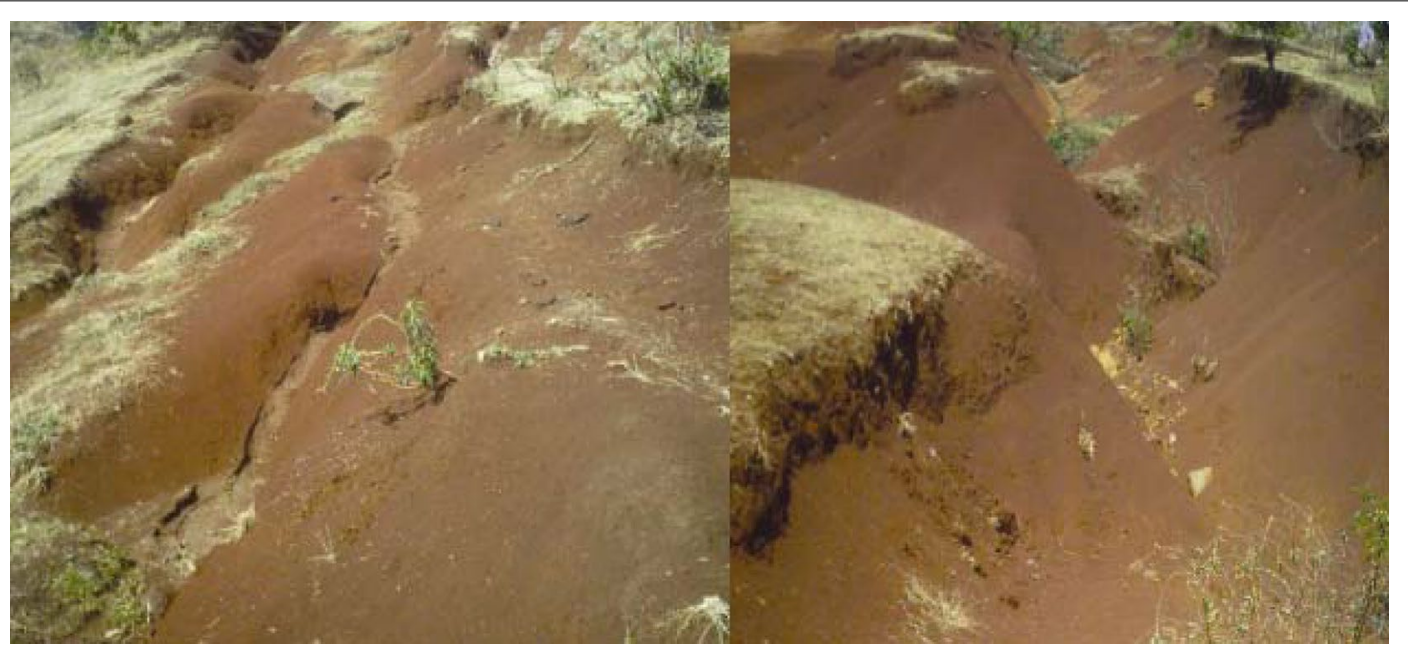

Fig. 9 Development of gully erosion in the exposed land of Gumara watershed (Photo by Mesfin, 2013) 
76.15 and $72.54 \%$ over the analysis period respectively. The study indicated that socio-economic factors mainly population pressure, expansion of agriculture, demand for fuel wood and construction material, poverty as well as policy and institutional changes were major driving forces in land use/cover dynamics behind. Such a situation has critical implications on the deterioration of natural resources such as biodiversity loss, soil erosion and shortage of firewood and construction material. This apparently tells us that it will continue to be development challenge of the watershed and the nation at large. Further research and development interventions into ecosystem dynamics at various scales are required if conservation and agricultural development goals for this watershed in particular and the country at large are to be met on sustainable basis.

\section{Authors' contributions}

Mesfin A has made substantial contributions in acquisition of data, data collection, entry, coding and analysis,interpretation of results,writing and leading the overall activities of the research. Mohammed A has substantially contributed in the design, drafting the manuscript and critically revising the manuscript for important intellectual content. He has given also the final approval of the version to be published. Melanie Nicolau has also been involved in critically revising the manuscript and suggestion. All authors read and approved the final manuscript.

\section{Author details}

1 Department of Geography and environmental studies, Bahir Dar University, Bahir Dar, Ethiopia. ${ }^{2}$ Department of Geography and environmental studies, Addis Ababa University, Addis Ababa, Ethiopia. ${ }^{3}$ Department of Geography, University of South Africa UNISA, Pretoria, South Africa.

\section{Acknowledgements}

The authors gratefully acknowledge the financial support they received from Bahir Dar University. The Gumara watershed community also deserve appreciation for their kind response to any requested information.

\section{Competing interests}

The authors declare that they have no competing interests.

Received: 18 November 2015 Accepted: 1 February 2016

Published online: 17 February 2016

\section{References}

Aklilu A (2006) Caring for the land: Best practices in soil and water conservation in Beressa watershed, highlands of Ethiopia (Tropical resource Management Papers no. 76). Wageningen University and Research Center, Wageningen
Amare S, Kao K (2012) Impacts of land use/cover dynamics of the gilgel abbay catchment of lake Tana on climate variability, Northwestern Ethiopia. Appl Geomat 3:155-163

Bedru S (2006) Remote sensing and GIS for Land use/cover change detection and analysis in the semi natural ecosystem and agricultural landscape of the Central Ethiopian Rift valley. Dresden University, Germany (Unpublished PhD dissertation).

Bezyayehu T, Gerret S (2008) Hydropower-induced land use change in Fincha'a watershed, Western Ethiopia: analysis and impacts. Mt Res Dev 28:72-80

Campbell DJ, Losch DP, Smucker TA (2005) Multiple methods in the study of driving forces of land use and land cover change: a case study of SE kajiado District Kenya. Human Ecol 33:763-794

Carr DI (2004) Tropical Deforestation. In: Janelle D, Hansen K (eds) Geographical perspective in 100 problems. Kluwer Academy, London

CSA (2007) Summary and statistical report of population and housing census of Ethiopia. Central Statistical Agency, Addis Ababa

EMS (2013) Ethiopian Meteorological Service data base (1973-2005). Ethiopian Meteorological Service, Addis Ababa

Foley JA, Defries R, Asner GP (2005) Global consequences of Land use. Science 309:570-574

Gete Z, Hurni H (2001) Implication and land use/land cover dynamics for mountain resource degradation in the Northwestern Ethiopia highlands. Mt Res Dev 21:184-191

Kebrom T, Hedlund L (2000) Land cover changes between 1958 and 1986 in Kalu, South Wollo, Ethiopia. Mt Res Dev 20:42-51

Lambin EF, Geist HJ (2001) What drives tropical deforestation? a metaanalysis of proximate and underlying causes of deforestation based on sub-National case study evidences. LUCC International project Office, Louvain-la-Neuve

Lambin EF, Geist HJ (2006) Land use and cover changes, local processes and global impact. Springer, Berlin

Mather AS, Needle CL (2000) The relationship of population and forest trends. Geogr J 166:2-13

McGranham G, Marcotulullio X, Bai D, Barga T (2005) Urban systems, current status and trends. Island Press, Washington

Meyer WB, Turner BL (1995) Human population growth and global land use and land cover change. Annu Rev Ecol Syst 23:39-61

Mohammed A (2011) Land use/cover dynamics and its implication in the drier lake Alemaya watershed, eastern Ethiopia. J Sustain Dev Afr 13:96-109

Sanderson EW, Reford KH, Veder A, Copolillo PB, Ward SE (2002) A conceptual model for conservation planning based on landscapes species requirements. Landsc Urban Plan 58:41-56

South Gondar Zone Office of Agriculture (2013). Population data base document of South Gondor Zone, 1984-2013(in Amharic). (Unpublished report pp.81). Debre Tabor

Turner BL, Meyer WB (1994) Change in land use and land cover, a global perspective. Cambridge University Press, Cambridge

Woldeamlak B (2002) Land cover dynamics since the 1950s in Chemoga watershed, Blue Nile basin, Ethiopia. Mt Res Dev 22:263-269

Zikre Hig of the Council of the Amhara National Regional State (1997) Proclamation no.17/1997. A proclamation to amend the proclamation that provides for the re allotment of the possession of rural land in the Amhara National Regional State, Bahir Dar, p 68 